Special Issue of the 8th International Advances in Applied Physics and Materials Science Congress (APMAS 2018)

\title{
Effects of Molybdenum and Boron Additions of Fe-Based Metal Matrix Composites by Warm Compaction Method
}

\author{
T. GÜN ${ }^{a, *}$ AND M. ŞIMŞIR ${ }^{b}$ \\ ${ }^{a}$ ESTAŞ Eksantrik San. ve Tic. A.Ş., 58060 Sivas, Turkey \\ ${ }^{b}$ Cumhuriyet University, Department of Metallurgy and Materials Eng., 58100 Sivas, Turkey
}

\begin{abstract}
In this study, mechanical behavior of iron base (Fe-0.8C-2.0Cu-3.0Ni-XMo-YB [wt\%] X $=1.2,1.8 ; \mathrm{Y}=0.2$, 1.0) metal matrix composite (MMC) was investigated for gear production by powder metallurgy (PM). MMC has produced by warm compaction method followed by free sintering in controlled Ar gas atmosphere. Green composite has produced under $650 \mathrm{MPa}$ pressure at $160^{\circ} \mathrm{C}$. The green products have been sintered at temperature 1050, 1150 and $1250^{\circ} \mathrm{C}$ for 90 minute. Effect of $\mathrm{Mo}$ and $\mathrm{B}$ additions were investigated on hardness, wear resistance, density and microstructure of the composite samples. The worn surfaces of the samples have been examined under scanning electron microscopy (SEM) and analyzed by energy dispersive spectroscopy (EDS) and X-ray diffraction method (XRD). The results have showed that hardness and wear resistance of the samples increases with increasing temperature and molybdenum and boron addition. The highest hardness and wear resistance have been obtained at the composite sample produced at $1250^{\circ} \mathrm{C}$ sintering temperature and $1.8 \% \mathrm{Mo}-\mathrm{B} 1.0 \%$ addition.
\end{abstract}

DOI: 10.12693/APhysPolA.135.819

PACS/topics: powder metallurgy, warm compaction, microstructure, composites, mechanical properties

\section{Introduction}

Manufacturing of mechanical components [1] by PM technology has been frequently used in the manufacturing industry due to its low energy consumption, efficient material utilization, and low cost of production resulting from the near net shape process [2]. Therefore, some PM structural parts with high sintered density as well as high wear resistance have found wide range of applications in the automotive systems, such as cam lobes, gears and valve seats, etc., mainly required for good wear resistance [3].

In the powder metallurgy method the parts formed with the cold-pressing process are sintered with different sintering methods (free sintering, hot press sintering, hot isostatic sintering, spark plasma sintering, microwave sintering etc.). In this study, the warm compaction method was used for performing of metal matrix composites. This technique consists in pressing a preheated powder in a heated die at temperature range from 90 to $150{ }^{\circ} \mathrm{C}$ typically. The green strength obtained from this approach is about two times larger than that provided by cold compaction [4-9]. By heating the powder mix and the press tool to $150^{\circ} \mathrm{C}$ an increase in density in the range $0.15-0.20 \mathrm{~g} / \mathrm{cm}^{3}$ over conventional compaction was reported [10].

The aim of this study is to produce Fe-based (Fe-0.8C-2.0Cu-3.0Ni-XMo-YB [\%]) metal matrix com-

*corresponding author; e-mail: tarik.gun@estas.com.tr posite by warm compacting method at three different sintering temperature $\left(1050^{\circ} \mathrm{C}, 1150^{\circ} \mathrm{C}, 1250^{\circ} \mathrm{C}\right)$ for gear production. The effect of Mo (1.2-1.8\%) and $\mathrm{B}$ $(0.2-1.0 \%)$ additions were investigated the mechanical properties of produced metal matrix composite for gear production.

\section{Materials and equipments}

The water atomized iron powder, together with nickel, copper, molybdenum, boron and graphite with purity higher than $99 \%$, were used for this experiment. The average diameters of particles were in the range of $<68 \mu \mathrm{m}$ for iron, $<44 \mu \mathrm{m}$ for copper, $<37 \mu \mathrm{m}$ for nickel, $<$ $88 \mu \mathrm{m}$ for molybdenum, $<15 \mu \mathrm{m}$ for boron powder and graphite powder. The composition of powder mixture is 0.8 wt\% C, 2 wt\% Cu, 3.0 wt\% Ni, (1.2-1.8) wt\% Mo, $(0.2-1.0)$ wt $\%$ B, 0.6 wt\% zinc stearate and iron base. The chemical composition for different specimens is given in Table I. The powder mixtures were homogenized in a mixer for $30 \mathrm{~min}$. The pre-heated mixed powders were pressed in a steel mold, increasing from room temperature to $160^{\circ} \mathrm{C}$. Compacting pressure was $650 \mathrm{MPa}$. Cylindrical specimens were obtained the dimension of $15 \times 10 \mathrm{~mm}$. The re-pressed compacts were sintered with an argon atmosphere, at three different temperatures of $1050,1150,1250^{\circ} \mathrm{C}$ and held $90 \mathrm{~min}$ in the sintering furnace for each temperature, respectively. The sintered specimens were tested to determine wear behavior, hardness, density and microstructure using SEM with EDS and XRD methods to wear surface and materials. The effects of the sintering temperature and time on material properties were investigated. 
Chemical composition of materials

TABLE I

\begin{tabular}{c|c|c|c|c|c|c}
\hline \hline \multirow{2}{*}{$\begin{array}{c}\text { Sintering } \\
\text { temp. }\left[{ }^{\circ} \mathrm{C}\right]\end{array}$} & \multicolumn{6}{|c}{ Chemical composition [\%] } \\
\cline { 2 - 7 } & $\mathrm{Ni}$ & $\mathrm{Mo}$ & $\mathrm{B}$ & $\mathrm{Cu}$ & $\mathrm{C}$ & $\mathrm{Fe}$ \\
\hline \multirow{2}{*}{1050} & 3 & 1.2 & 0.2 & 2 & 0.8 & rest \\
& 3 & 1.8 & 1 & 2 & 0.8 & rest \\
\hline \multirow{2}{*}{1150} & 3 & 1.2 & 0.2 & 2 & 0.8 & rest \\
& 3 & 1.8 & 1 & 2 & 0.8 & rest \\
\hline \multirow{2}{*}{1250} & 3 & 1.2 & 0.2 & 2 & 0.8 & rest \\
& 3 & 1.8 & 1 & 2 & 0.8 & rest
\end{tabular}

\section{Results and discussion}

\subsection{Hardness results}

Hardness tests were conducted in the INSTRONWOLPERT macro hardness testers. HRA hardness values of the specimens were measured by using $60 \mathrm{kgf}$ loads. Five hardness measurements were carried out for each sample and the mean of the hardness and density values are given in Table II.
As it is seen, the hardness and the density values increases with increasing sintering temperature and according to the amount of boron and molybdenum added. The maximum hardness was obtained in composition $(3.0 \% \mathrm{Ni}-1.8 \% \mathrm{Mo}-1.0 \% \mathrm{~B}-2.0 \% \mathrm{Cu}-0.8 \% \mathrm{Cu}$-rest $\mathrm{Fe})$ at $1250{ }^{\circ} \mathrm{C}$ for 90 minutes. The amount of hardness seems to be growing with increasing sintering temperature. Increased molybdenum and boron content increases material hardness in increasing sintering temperature. The maximum hardness and density was obtained in the sintered composition $(3.0 \% \mathrm{Ni}-1.8 \% \mathrm{Mo}-1.0 \% \mathrm{~B}-2.0 \% \mathrm{Cu}-0.8 \% \mathrm{Cu}$-rest $\mathrm{Fe})$ at $1250^{\circ} \mathrm{C}$ for $90 \mathrm{~min}$.

\subsection{Microstructure results}

Metallographic sections were prepared by grinding, diamond polishing, and etching with $2 \%$ nital for 5-10 s. The metallographic observations were conducted on a metal microscope Nikon Eclipse MA200. Figure 1 shows the metallographic structure of the samples after nital etching.

Composition [\%], hardness and density values of materials

TABLE II

\begin{tabular}{c|c|c|c|c|c|c|c|c|c}
\hline \hline No & $\begin{array}{c}\text { Sintering } \\
\text { temp. }\left[{ }^{\circ} \mathrm{C}\right]\end{array}$ & $\mathrm{Ni}$ & $\mathrm{Mo}$ & $\mathrm{B}$ & $\mathrm{Cu}$ & $\mathrm{C}$ & $\mathrm{Fe}$ & HRa & $\begin{array}{c}\text { Density } \\
{\left[\mathrm{g} / \mathrm{cm}^{3}\right]}\end{array}$ \\
\hline 1 & \multirow{2}{*}{1050} & 3 & 1.2 & 0.2 & 2 & 0.8 & rest & 48.8 & 7.01 \\
2 & & 3 & 1.8 & 1 & 2 & 0.8 & rest & 51.1 & 7.10 \\
\hline 3 & \multirow{2}{*}{1150} & 3 & 1.2 & 0.2 & 2 & 0.8 & rest & 57.3 & 7.05 \\
4 & & 3 & 1.8 & 1 & 2 & 0.8 & rest & 66.4 & 7.12 \\
\hline 5 & \multirow{2}{*}{1250} & 3 & 1.2 & 0.2 & 2 & 0.8 & rest & 65.5 & 7.04 \\
6 & & 3 & 1.8 & 1 & 2 & 0.8 & rest & 67.5 & 7.15
\end{tabular}
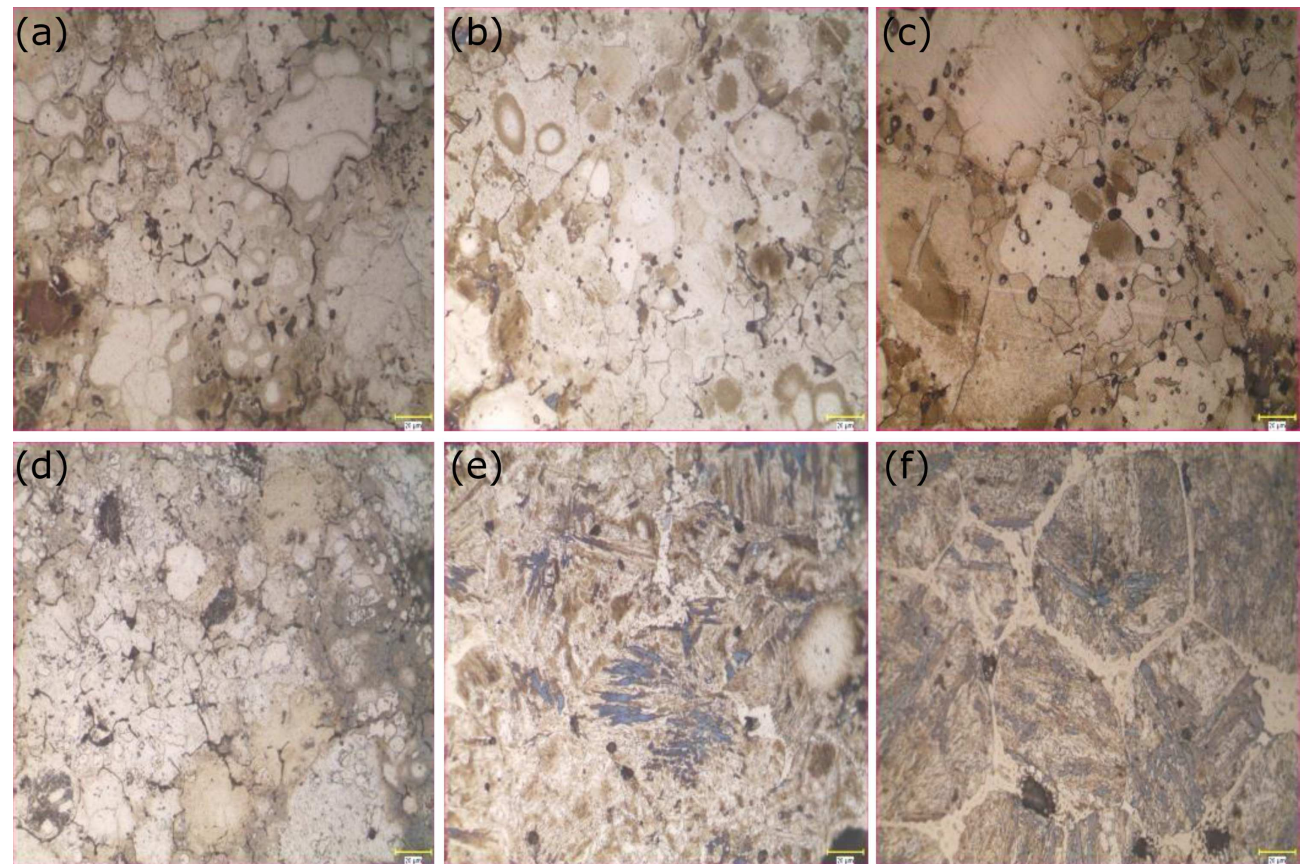

Fig. 1. Microstructure of samples $(500 \times) ; 3.0 \% \mathrm{Ni}-1.2 \% \mathrm{Mo}-0.2 \mathrm{~B} \%-2.0 \mathrm{Cu} \%-0.8 \mathrm{C} \%$ composition sintered at (a) $1050{ }^{\circ} \mathrm{C}$ for $90 \mathrm{~min}$, (b) $1150^{\circ} \mathrm{C}$ for $90 \mathrm{~min}$ (c) $1250^{\circ} \mathrm{C}$ for $90 \mathrm{~min}$. Microstructure of samples (500×); $3.0 \% \mathrm{Ni}-1.8 \% \mathrm{Mo}-1.0 \mathrm{~B} \%$ $2.0 \mathrm{Cu} \%-0.8 \mathrm{C} \%$ composition sintered at (d) $1050{ }^{\circ} \mathrm{C}$ for $90 \mathrm{~min}$, (e) $1150{ }^{\circ} \mathrm{C}$ for $90 \mathrm{~min}$ (f) $1250{ }^{\circ} \mathrm{C}$ for $90 \mathrm{~min}$ 
The microstructure of the sintered samples have showed increase of copper solubility in the matrix and subsiding to the grain boundary with increasing sintering temperature and time. Mo and $\mathrm{Cu}$ addition caused the formation of ferritic and regional bainitic microstructure. Changes in the ferrite grain shape and distribution has been observed with the increases sintering temperature.

Figure 1 shows the microstructure photographs of the $3.0 \% \mathrm{Ni}-1.2 \% \mathrm{Mo}-0.2 \mathrm{~B} \%-2.0 \mathrm{Cu} \%-0.8 \mathrm{C} \%$ and $3.0 \% \mathrm{Ni}-1.8 \% \mathrm{Mo}-1.0 \mathrm{~B} \%-2.0 \mathrm{Cu} \%-0.8 \mathrm{C} \%$ compositions at $1000{ }^{\circ} \mathrm{C}, 1150{ }^{\circ} \mathrm{C}$ and $1250^{\circ} \mathrm{C}$ temperature and 90 minutes sintering time. The influence of the initial particle size on the austenite grain size is visible. Increasing in the sintering time at $1050{ }^{\circ} \mathrm{C}$ resulted in austenite grains which were approximately double the size. But austenite grains are changing phase with increases sintering temperature.

\subsection{Wear test results}

Wear tests were carried out by Nanove brand "Ball-ondisc" type wear apparatus. The wear tests were carried out under load of $30 \mathrm{~N}$, at $300 \mathrm{rpm}$ speed and sliding distances of $100 \mathrm{~m}$. Then the friction coefficient and weight loss were measured. Figure 2 shows the relationship between weight loss and friction coefficient for various sintering process.

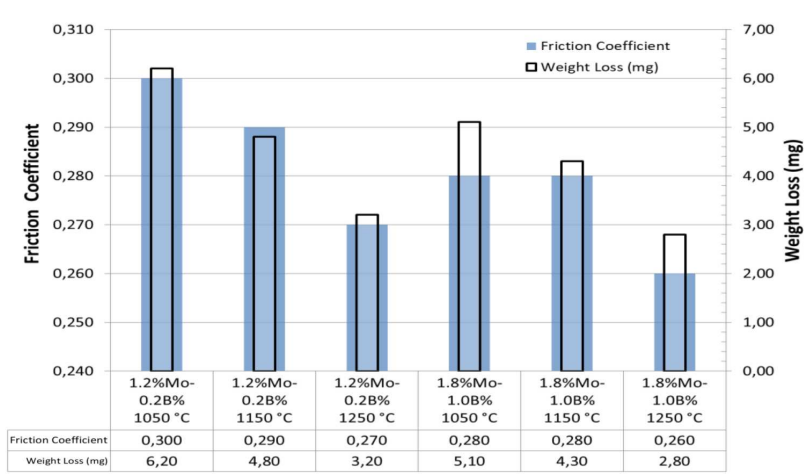

Fig. 2. Wear test results of sintered samples at $1050{ }^{\circ} \mathrm{C}, 1150{ }^{\circ} \mathrm{C}, 1250{ }^{\circ} \mathrm{C}$ for 90 min (Base powders $3.0 \% \mathrm{Ni}, 2.0 \% \mathrm{Cu}, 0.8 \% \mathrm{C}$, rest $\mathrm{Fe}$ ).
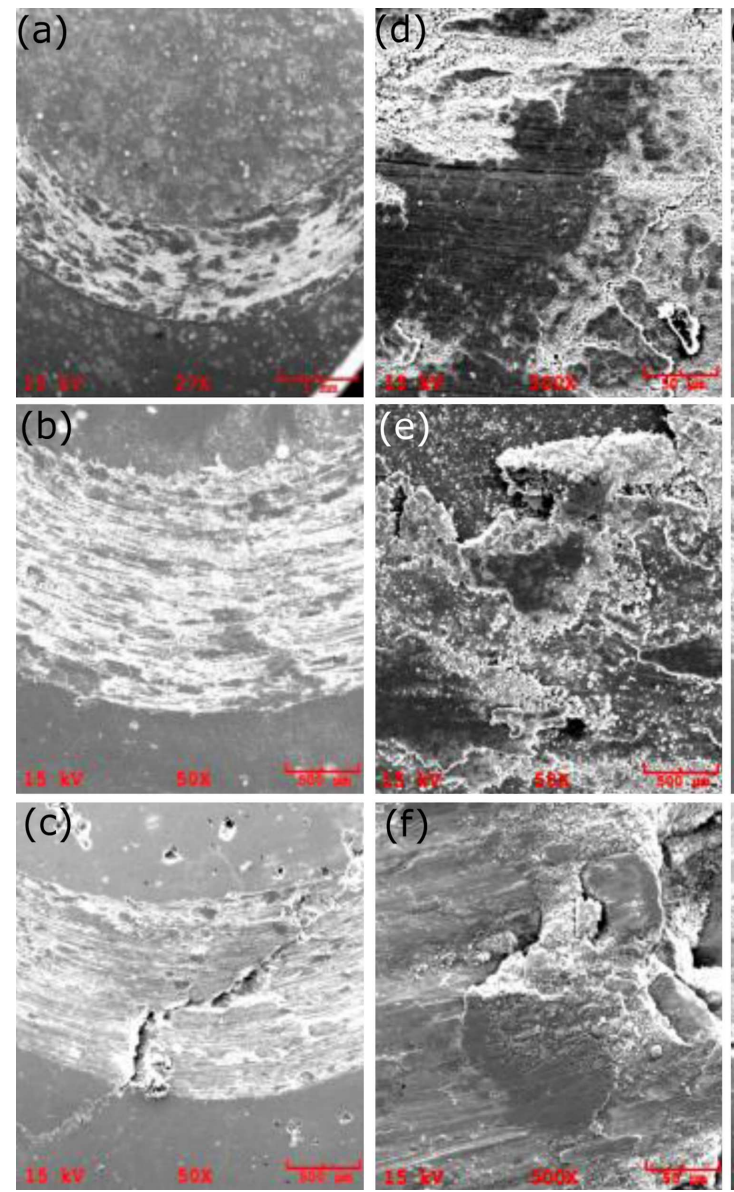
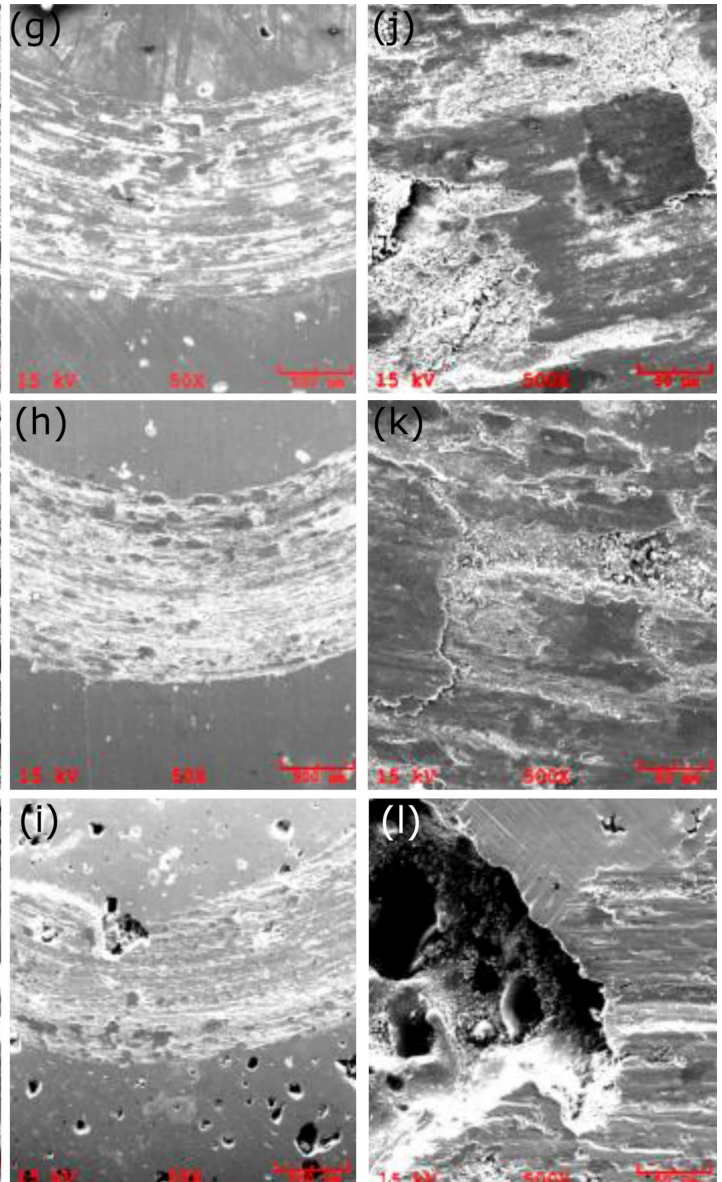

Fig. 3. Wearing surface SEM images of samples $(3.0 \% \mathrm{Ni}-1.2 \% \mathrm{Mo}-0.2 \mathrm{~B} \%-2.0 \mathrm{Cu} \%-0.8 \mathrm{C} \%)$ at (a) $1050^{\circ} \mathrm{C}(50 \times)$

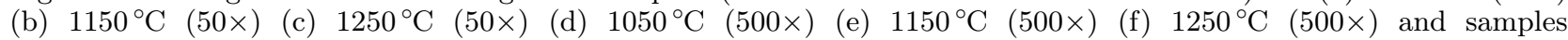
$(3.0 \% \mathrm{Ni}-1.8 \% \mathrm{Mo}-1.0 \mathrm{~B} \%-2.0 \mathrm{Cu} \%-0.8 \mathrm{C} \%)$ at $(\mathrm{g}) 1050^{\circ} \mathrm{C}(50 \times)(\mathrm{h}) 1150^{\circ} \mathrm{C}(50 \times)(\mathrm{i}) 1250{ }^{\circ} \mathrm{C}(50 \times)(\mathrm{j}) 1050{ }^{\circ} \mathrm{C}(500 \times)$

(k) $1150^{\circ} \mathrm{C}(500 \times)(\mathrm{l}) 1250^{\circ} \mathrm{C}(500 \times)$ samples for $90 \mathrm{~min}$. 
The highest coefficient of friction was measured in the sample sintered at $1050{ }^{\circ} \mathrm{C}$ for 90 minutes. Minimum sample loss was measured $2.3 \mathrm{mg}$ result of an increase in the surface hardness in sintered at $1250{ }^{\circ} \mathrm{C}$ for 90 minutes. Minimum material loss was obtained in the composition with $1.8 \%$ Mo and $1.0 \% \mathrm{~B}$ added.

\subsection{Worn surfaces in SEM analysis}

SEM analyzes were conducted to characterize the wear surface as a result of the wear test. At this wear condition two wear mechanisms adhesive wear and abrasive wear coexist. Mainly adhesive wear seen in all sample but it also shows partly abrasive wear, as the ball hardness remained high compared to all samples, that mainly the adhesive wear is considered normal. The worn surface of the samples is characteristic of adhesive wear and this can also be supported by the coarsening ball surface. Figure 3 shows the wear images of sintered samples at different sintering temperatures.

Figures 4-9 show the EDX analyzes of the samples sintered at different temperatures for 90 minutes. SEM image and 3 different points were analyzed For each EDX analysis.

The results of SEM analysis of the samples studied are composed of two different grayscale phase. Probably dark gray section accommodates including iron-carbon grains. Light colored matrix grains have including iron-nickel and some copper.

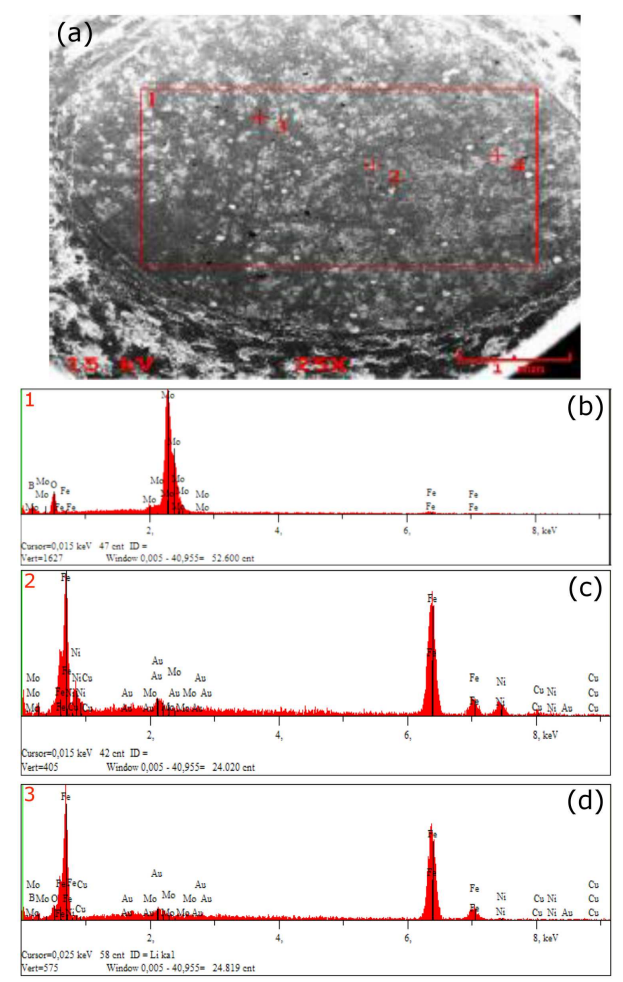

Fig. 4. SEM and EDX analysis of $3.0 \% \mathrm{Ni}-1.2 \% \mathrm{Mo}-$ $0.2 \mathrm{~B} \%-2.0 \mathrm{Cu} \%-0.8 \mathrm{C} \%$ composition (a) SEM-BEI image, (b) spot 1 , (c) spot 2 , (d) spot 3 , sintered at $1050^{\circ} \mathrm{C}$ for $90 \mathrm{~min}$.
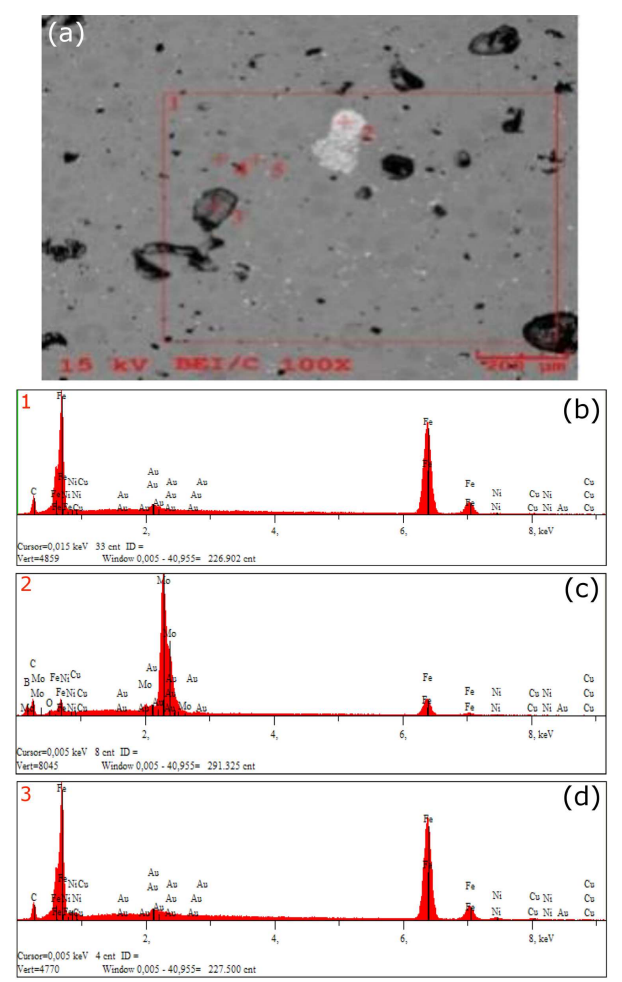

Fig. 5. SEM + EDX analysis of $3.0 \% \mathrm{Ni}-1.2 \% \mathrm{Mo}-$ $0.2 \mathrm{~B} \%-2.0 \mathrm{Cu} \%-0.8 \mathrm{C} \%$ composition (a) SEM-BEI image, (b) spot 1 , (c) spot 2 , (d) spot 3 sintered at $1150^{\circ} \mathrm{C}$ for $90 \mathrm{~min}$.

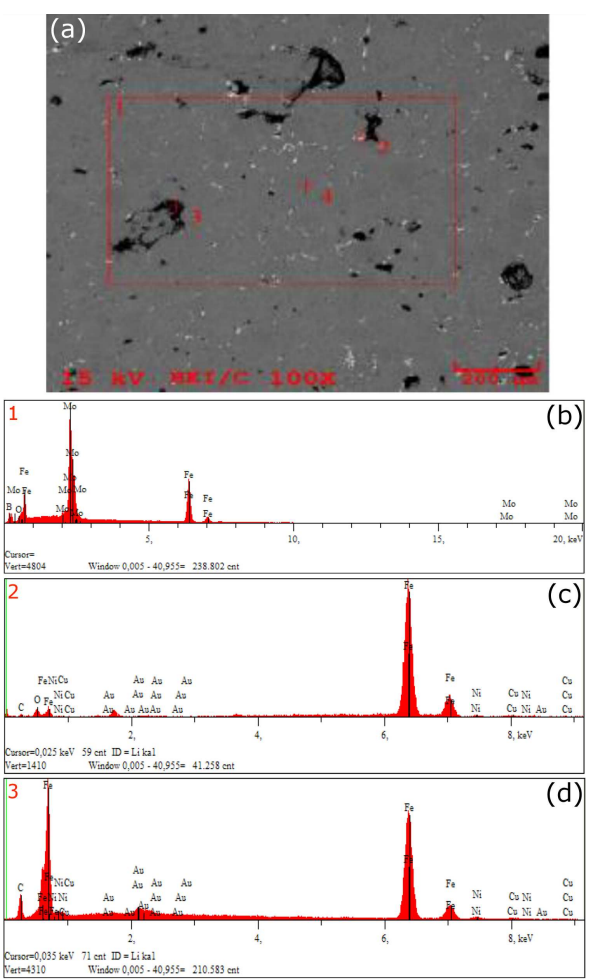

Fig. 6. SEM + EDX analysis of $3.0 \% \mathrm{Ni}-1.2 \% \mathrm{Mo}-$ $0.2 \mathrm{~B} \%-2.0 \mathrm{Cu} \%-0.8 \mathrm{C} \%$ composition (a) SEM-BEI image, (b) spot 1 , (c) spot 2 , (d) spot 3 sintered at $1250^{\circ} \mathrm{C}$ for $90 \mathrm{~min}$. 


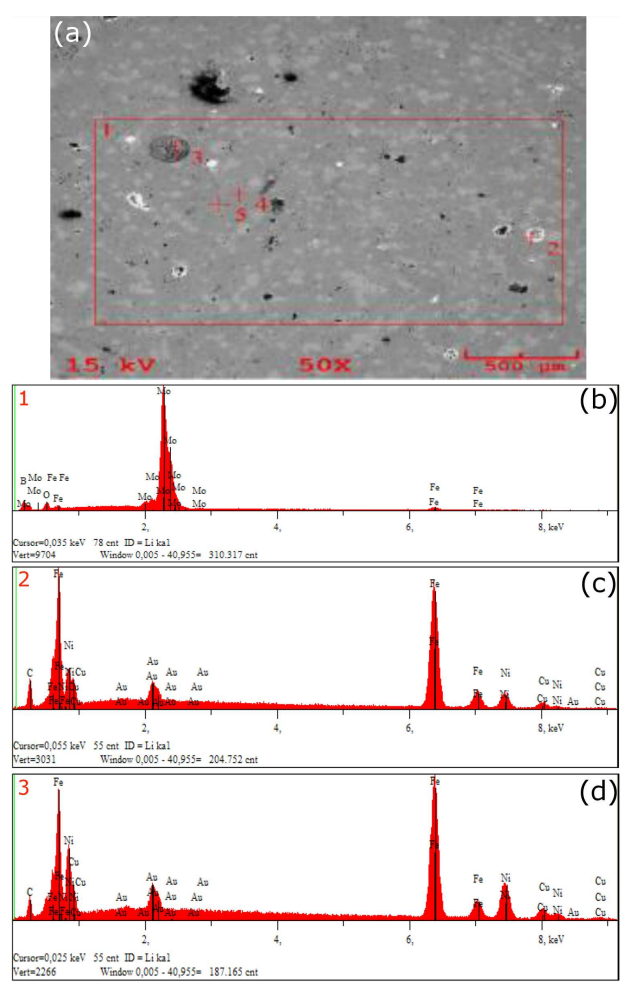

Fig. 7. SEM + EDX analysis of $3.0 \% \mathrm{Ni}-1.8 \% \mathrm{Mo}-$ 1.0B\%-2.0Cu\%-0.8C\% composition (a) SEM-BEI image, (b) spot 1 , (c) spot 2 , (d) spot 3 sintered at $1050^{\circ} \mathrm{C}$ for $90 \mathrm{~min}$.

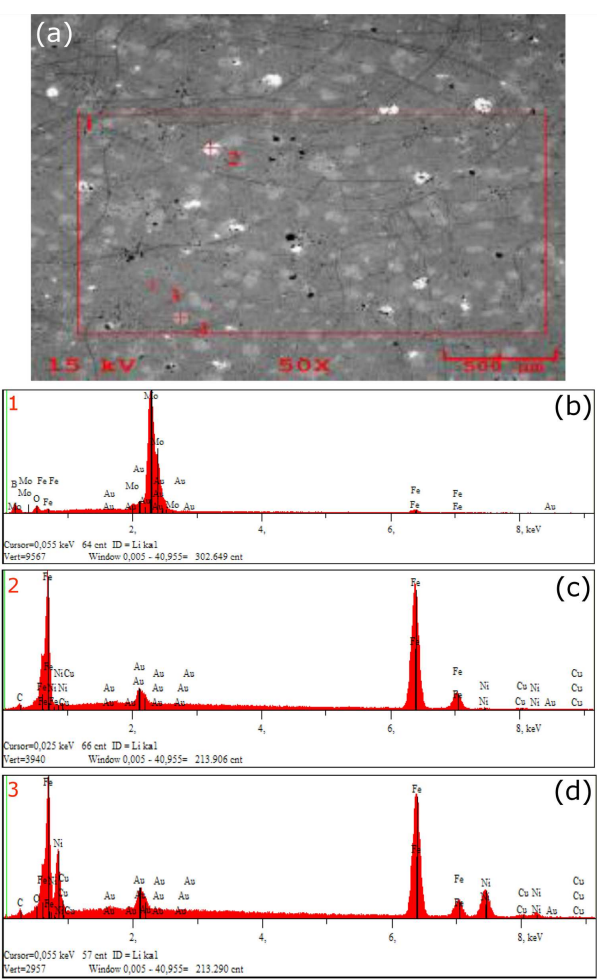

Fig. 8. SEM + EDX analysis of $3.0 \% \mathrm{Ni}-1.8 \% \mathrm{Mo}-$ 1.0B\%-2.0Cu\%-0.8C\% composition (a) SEM-BEI image, (b) spot 1, (c) spot 2 , (d) spot 3 sintered at $1150^{\circ} \mathrm{C}$ for $90 \mathrm{~min}$

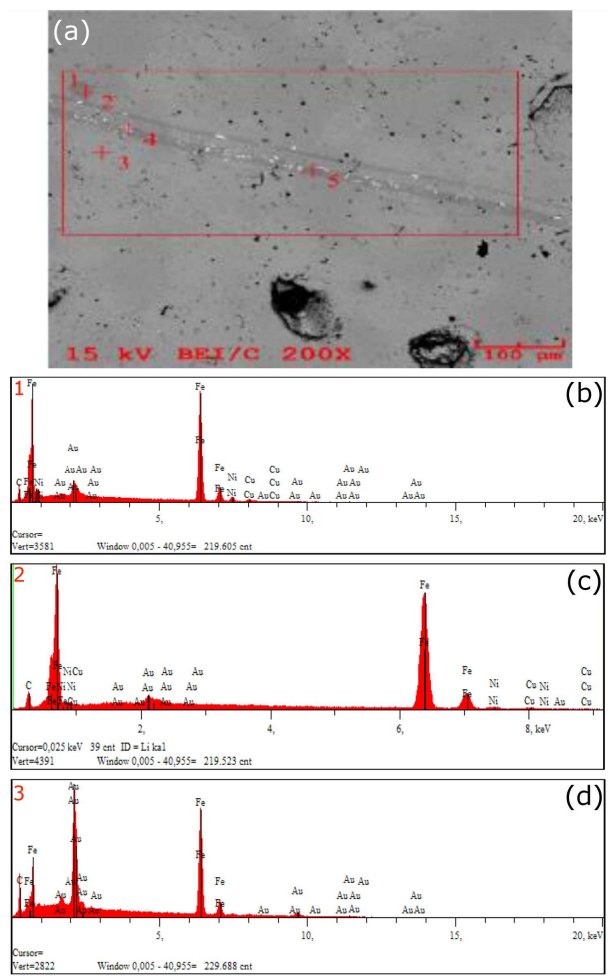

Fig. 9. SEM + EDX analysis of $3.0 \% \mathrm{Ni}-1.8 \% \mathrm{Mo}-$ 1.0B\%-2.0Cu\%-0.8C\% composition (a) SEM-BEI image, (b) spot 1 , (c) spot 2 , (d) spot 3 sintered at $1250^{\circ} \mathrm{C}$ for $90 \mathrm{~min}$.

White spots are seen as Mo elements. The main chemical elements were identified as carbon $(\mathrm{C})$, iron $(\mathrm{Fe})$, molybdenum (Mo), cupper $(\mathrm{Cu})$ boron $(\mathrm{B})$, nickel $(\mathrm{Ni})$. The solubility of alloying elements increases in Fe-based with increasing sintering temperature.

\subsection{X-Ray diffraction}

Figures 10 and 11 show XRD patterns of the specimens after different sintering processes. As indicated in these spectra, the peaks is show of iron (Fe) element in the samples.

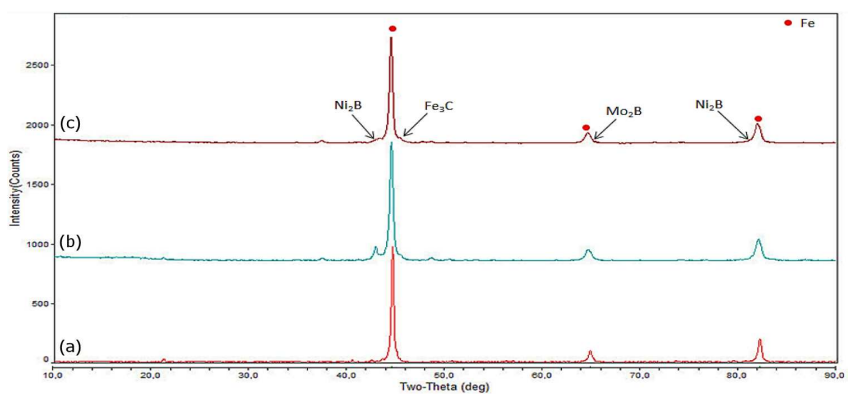

Fig. 10. XRD patterns of $3.0 \% \mathrm{Ni}-1.2 \% \mathrm{Mo}-0.2 \mathrm{~B} \%$ $2.0 \mathrm{Cu} \%-0.8 \mathrm{C} \%$ composition at (a) $1050{ }^{\circ} \mathrm{C}$, (b) $1150{ }^{\circ} \mathrm{C}$, (c) $1250{ }^{\circ} \mathrm{C}$ for $90 \mathrm{~min}$. 


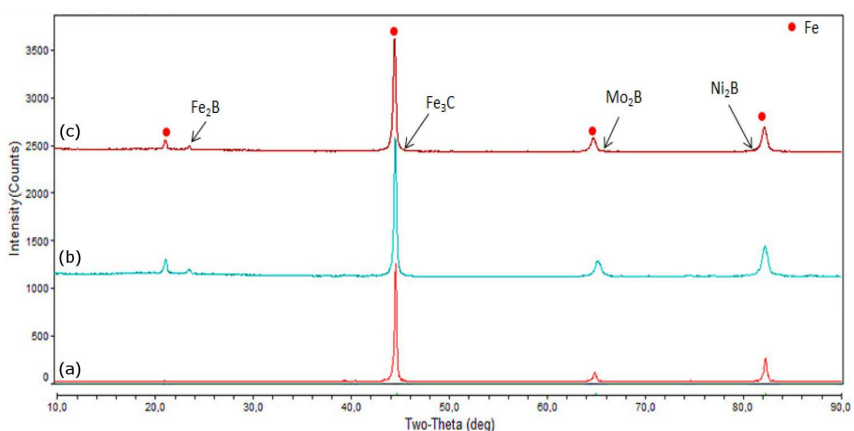

Fig. 11. XRD patterns of $3.0 \% \mathrm{Ni}-1.8 \% \mathrm{Mo}-1.0 \mathrm{~B} \%$ 2.0 $\mathrm{Cu} \%-0.8 \mathrm{C} \%$ composition at (a) $1050{ }^{\circ} \mathrm{C}$, (b) $1150{ }^{\circ} \mathrm{C}$, (c) $1250{ }^{\circ} \mathrm{C}$ for $90 \mathrm{~min}$.

It is observed that the formation of $\mathrm{Fe}_{3} \mathrm{C}, \mathrm{Ni}_{2} \mathrm{~B}, \mathrm{Mo}_{2} \mathrm{~B}$ on the edges of iron peak. Length of the iron peaks decreased with increasing temperature and time. This is because additive elements is due to the dissolution in iron at high sintering temperature.

It is observed that the formation of $\mathrm{Fe}_{3} \mathrm{C}, \mathrm{Ni}_{2} \mathrm{~B}, \mathrm{Mo}_{2} \mathrm{~B}$ and $\mathrm{Fe}_{2} \mathrm{~B}$ on the edges of iron peak Addition of $1 \%$ Boron has creating compound by reaction with nickel and molybdenum. The size of the pigs is increasing with the increase of boron addition.

\section{Conclusions}

The aim of this study is to produce Fe-based (Fe-0.8C-2.0Cu-3.0Ni-XMo-YB [\%]) metal matrix composite by warm compacting method at three different sintering temperature $\left(1050^{\circ} \mathrm{C}, 1150^{\circ} \mathrm{C}, 1250^{\circ} \mathrm{C}\right)$ for gear production. The effect of $\mathrm{Mo}(\% 1.2-1.8)$ and $\mathrm{B}(\% 0.2-1.0)$ additions were investigated to the mechanical properties of produced metal matrix composite for gear production. The hardness values increases with increasing sintering temperature and boron and molybdenum addition. The highest hardness value was obtained in samples with $\mathrm{Fe}-0.8 \mathrm{C}-2.0 \mathrm{Cu}-3.0 \mathrm{Ni}-1.8 \mathrm{Mo}-1.0 \mathrm{~B}$ composition in sintered at $1250^{\circ} \mathrm{C}$ for 90 minutes. The highest density is obtained in the same sample. The lowest friction coefficient was obtained 0.3 at sintered $1050^{\circ} \mathrm{C}$ for 90 minutes in the $\mathrm{Fe}-0.8 \mathrm{C}-2.0 \mathrm{Cu}-3.0 \mathrm{Ni}-1.8 \mathrm{Mo}-1.0 \mathrm{~B}$ composition samples. Minimum sample loss has also been $2.9 \mathrm{mg}$ in the same sample. Generally the amount of wear also increases in parallel with the friction coefficient in wear test. The formation of bainite structure was found in microstructure with increasing sintering temperature. If the material contains bainitic structure it exhibits low wear rate.

\section{References}

[1] J. Georgiev, T. Pieczonka, M. Stoytchev, D. Teodosiev, Surf. Coat. Technol. 180-181, 90 (2004).

[2] J. Wang, H. Danninger, Wear 222, 49 (1998).

[3] A. Fujiki, Mater. Chem. Phys. 67, 298 (2001).

[4] G. Sundararajan, S.V. Joshi, L.R. Krishna, Curr. Op. Chem. Eng. 11, 1 (2016).

[5] E. Robert-Perron, C. Blais, S. Pelletier, Y. Thomas, Mat. Sci. Eng. A 458, 195 (2006).

[6] M. Azadbeh, N. Parvini Ahmadi, Curr. Appl. Phys. 9, 777 (2009).

[7] H.A. Al-Qureshi, M.R.F. Soares, D. Hotza, M.C. Alves, A.N. Klein, J. Mat. Proc. Techn. 199, 417 (2009).

[8] E. Robert-Perron, C. Blais, S. Pelletier, Martin Dionne, Mat. Sci. Eng. A 402, 334 (2005).

[9] E. Robert-Perron, C. Blais, S. Pelletier, Y. Thomas, Metall. Mat. Trans. A 38, 1330 (2007).

[10] A. Babakhani, A. Haerian, in: Mat. Sci. Forum, Vols. 638-642, Eds. T. Chandra, N. Wanderka, W. Reimers, M. Ionescu, 2010, p. 1802. 